\title{
Intracranial Hemorrhage Related to Birth
}

National Cancer Institute

\section{Source}

National Cancer Institute. Intracranial Hemorrhage Related to Birth. NCI Thesaurus.

Code C116910.

Bleeding within the skull of a newborn infant occurring during labor and/or delivery. 